\title{
Charakterystyka semantyczna wyrażeń chcac nie chcac i mimo woli
}

Słow a klucze: wola; myślenie; wybór; modalność; eksplikacja semantyczna

Ke y w or d s: will; thinking; choice; modality; semantic explication

\section{Jednostki języka czy produkty systemu językowego?}

W artykule dotyczącym wolności woli Andrzej Bogusławski pisze: „Odpowiedniość wola - chcenie wydaje się intuicyjnie (...) oczywista. Nie należy jednak zapominać o tym, że rzeczownik wola bywa używany w zwrotach, w których bynajmniej nie odpowiada mu „,chcenie czynności”, lecz wprost sama czynność. Są to bodaj zwroty częstsze niż te, w których wola wiąże się wyłącznie z chceniem” (Bogusławski 1990: 197-198). Jednym z wyrażeń będących przedmiotem rozważań zawartych w niniejszym artykule jest jednostka, w której wola (wbrew pozorom) nie odpowiada wprost czynności - mam na myśli jednostkę mimo woli. Drugim badanym w niniejszej pracy wyrażeniem jest chcac nie chcac - jednostka o imiesłowowej proweniencji.

Wprawdzie wyrażenia te są odnotowane i zdefiniowane w słownikach języka polskiego, nie natrafiłam jednak dotąd na wyczerpującą analizę, która dotyczyłaby statusu ciągów mimo woli i chcac nie chcac. Dlatego koniecz- 
ne jest, moim zdaniem, wyjaśnienie, dlaczego należy uznać je za jednostki języka, a tym samym za obiekty mogące stanowić przedmiot analizy semantycznej. Uwagi na temat statusu sekwencji mimo woli zawarłam w innej pracy (Żochowska 2012), dlatego w tym miejscu przytoczę tylko najistotniejsze argumenty, przemawiające za tym, by ciąg ten uznać za jednostkę języka. O tym, że mimo woli nie jest produktem systemu językowego świadczy przede wszystkim fakt, że segmenty tej sekwencji należą do klas substytucyjnych zamkniętych jednoelementowych - potwierdza to niemożliwość podstawienia za któryś z jej segmentów innego wyrazu, por.:

(1) Zranitem ja mimo woli.

(2) *Zranitem ja mimo wiedzy.

(3) *Zranitem ja pomimo woli.

(4) *Zraniłem ja przeciw woli.

(5) Zranitem ja wbrew woli. (zmiana znaczenia)

Z kolei w uzasadnieniu, dlaczego za jednostkę języka należy uznać także sekwencję chcac nie chcac, pomocne będzie pokazanie różnic składniowych i semantycznych, jakie zachodzą między badanym ciagiem a imiesłowem chcac. Jak słusznie zauważa m. in. Henryk Wróbel, imiesłów chcac występuje w zdaniu z aby, żeby lub z bezokolicznikiem¹ (Wróbel 1975: 65-70), co widać w zdaniach, takich jak (przykłady za Wróblem):

(6) Nie chcac, aby ksiadz pomyślat, że mnie uroczystość krępuje, przyznatem się, dlaczego nie mam ochoty mu towarzyszyć.

(7) Chcac mu okazać serce, kupiłem kwiaty.

Sekwencja chcac nie chcac natomiast nie dopuszcza ani formy bezokolicznikowej czasownika, ani spójników aby czy żeby, wymaga za to osobowej formy czasownika:

(8) *Chcac nie chcqc, aby ksiqdz pomyślat, że mnie uroczystość krępuje, przyznałem się, dlaczego nie mam ochoty mu towarzyszyć.

(9) *Chcac nie chcac mu okazać serce, kupiłem kwiaty.

1 Podobnie zresztą, jak czasownik chcieć w formie osobowej. 
Segmenty ciągu chcac nie chcac należą do klas substytucyjnych zamkniętych - zamiana któregoś z elementów powoduje dewiację zdania:

(10) Chcac nie chcac, uczestniczytem w catym tym zamieszaniu.

(11) *Chcac nie pragnac uczestniczytem w calym tym zamieszaniu.

Warto też zauważyć, że oba badane wyrażenia wchodzą w czwórkowe układy proporcjonalne, por.:

mimo woli zranit: świadomie zranit = mimo woli unikam: świadomie unikam

chcac nie chcac uczestniczę: chętnie uczestniczę = chcac nie chcac pomagam: chętnie pomagam,

spełniają zatem podstawowy, wg Bogusławskiego (Bogusławski 1993), warunek nakładany na jednostki języka.

Wszystkie wymienione wyżej argumenty skłaniają mnie do uznania sekwencji mimo woli i chcac nie chcqc za jednostki języka.

\section{Wola - wiedza - wybór}

Arystoteles w Etyce Nikomachejskiej stwierdza: „za niezależne od woli uchodzą te rzeczy, których się dokonywa bądź pod przymusem, bądź skutkiem nieświadomości" (Arystoteles 1956: 73). Dalej pisze o czynnościach wykonywanych mimo woli - zaznacza, że są to te czynności, które wiążą się nieświadomością okoliczności jednostkowych. Według Arystotelesa „można nie zdawać sobie sprawy z tego, co się czyni - tak np. kiedy ludzie mówią, że im się coś wymknęło lub, że nie wiedzieli, iż o czymś mówić nie wolno lub kiedy ktoś, chcąc pokazać katapultę, wypuścił pocisk. W (...) tych wypadkach mamy do czynienia z nieświadomością i uważa się, że ktoś, kto nie zdawał sobie sprawy z jednej z tych rzeczy, dokonał czynu mimo woli (...) przyczyną postępowania od woli niezależnego jest (...) nieznajomość okoliczności jednostkowych, tj. warunków, w których czynu się dokonuje i przedmiotów, których on dotyczy. (...) Człowiek, któremu nie znane są któreś z tych okoliczności jednostkowych, postępuje niezależnie od woli” (Arystoteles 1956: 77-79). 
Cytowanych słów nie można oczywiście traktować jako odpowiedzi na pytanie o znaczenie jednostki mimo woli (choć może nieprzypadkowo tłumacz użył tego wyrażenia), jednak myśl Arystotelesa pokazuje jedną z zależności, jakie należy uwzględnić w analizie zarówno jednostki mimo woli, jak i innych wyrażeń „mimowolnych” - w tym również jednostki chcqc nie chcac. Chodzi mianowicie o związek między wolą a wiedzą.

Definicje słownikowe badanych przeze mnie wyrażeń nie zdają sprawy (w sposób wyczerpujący) z tego, jak wspomniane jednostki wyrażają tę relację. W dziełach leksykograficznych mimo woli znaczy po prostu tyle, co 'bez uprzedniego zamiaru, mimowolnie, bezwiednie, odruchowo, machinalnie, niekiedy także: wbrew woli, chęci' (SJPDor), 'bez uprzedniego zamiaru, bezwiednie, machinalnie, także: wbrew uprzedniemu zamiarowi, wbrew chęci, mimowolnie' (SJPSz), 'bez świadomego, uprzedniego zamiaru, bezwiednie, odruchowo, mimowolnie'(SWJP), '(...) bez zamiaru zrobienia tego, a czasem nawet wbrew własnej chęci (ISJP), 'bez uprzedniego zamiaru, bezwiednie, machinalnie; także wbrew uprzedniemu zamiarowi, wbrew chęci, mimowolnie' (USJP), natomiast chcac nie chcac jest definiowane jako 'mimo woli, wbrew własnej woli‘ (SJPD, SJPSz, SWJP, USJP) i ‘z konieczności’ (SWJP)².

Celem niniejszego artykułu jest m.in. ustalenie, co jednostki mimo woli i chcac nie chcac mówią zarówno o woli działającego, jak i o jego wiedzy - nie tylko na temat własnego działania, ale również na temat „okoliczności jednostkowych”. Istotne będzie dla mnie oczywiście rozstrzygnięcie, jakich to okoliczności jednostkowych nie zna (lub jakie zna) ten, którego czynność określamy interesującymi mnie wyrażeniami. Postaram się również pokazać, do którego etapu działania odnoszą się badane jednostki, tj. czy mówią o samym przebiegu czynności czy o momencie sprzed jej rozpoczęcia.

Istotna będzie dla mnie również kwestia aspektu czasowników określanych przez badane wyrażenia, tj. odpowiedź na pytanie, czy interesujące mnie jednostki odnoszą się do tego, co już zrobiono ${ }^{3}$, tzn. do zdarzeń czy też do czynności nieskończonych. Od omówienia tej właśnie kwestii rozpocznę niniejsze rozważania.

2 W ISJP odnajdujemy informację, mówiąca, że, ,jeśli ktoś chcąc nie chcąc coś robi, to robi to nie z własnej woli, ale zmuszony przez jakąś osobę lub sytuację".

3 Forma zrobiono nie świadczy o aprobowaniu podejścia redukcyjnego w analizie semantycznej - przeciwko któremu to podejściu argumenty podawała Duraj-Nowosielska (por. Duraj-Nowosielska 2007). 
Obserwując zdania z przysłówkiem mimo woli, zauważyć można, że zawsze określa on to, co zostało już zrobione ${ }^{4}$, nie zaś to, co trwa czy trwało, por:

(12) Nie wiedzac, że grupa Łasiczki wyszła już z lasu, zastępowy mimo woli wprowadzit dziewczyne w bład.

(13) Niezręczna sytuacja, jaka mimo woli stworzytem, wymagała zamknięcia.

(14) Uczestnik szarpnat się i zademonstrowat mimo woli jakość mocowań.

(15) $W$ tej chwili tak żywo stanęty mi w pamięci młode lata, że mimo woli spojrzałem na piec, pewny, że zobaczę woźnego z rózga i ławkę, na której bito $w$ skórę.

(16) Wygladało to tak, jakby Eryk wymykat się na schadzke; Kazimierz mimo woli pomyślat o tamtej nagiej, jeszcze mokrej kobiecie.

(17) Ale zioła tam na pewno maja - rzekt z takim przekonaniem, że uśmiechnęłam się mimo woli.

(18) ?Nie wiedzac, że grupa Łasiczki wyszła już z lasu, zastępowy mimo woli wprowadzat dziewczyne w bład.

(19) ?Uczestnik szarpat się i mimo woli demonstrowat jakość mocowań.

(20) ?Wygladało to tak, jakby Eryk wymykat się na schadzke; Kazimierz mimo woli myślat o tamtej nagiej, jeszcze mokrej kobiecie.

(21) ?Ale zioła tam na pewno maja - rzekł z takim przekonaniem, że później przez kwadrans uśmiechałam mimo woli.

${ }^{4}$ Co nie znaczy, że badany przysłówek nigdy nie pojawia się w sąsiedztwie czasowników w formie niedokonanej. Zawsze jednak odnoszą się one semantycznie do znaczenia dokonanego - wyrażają np. wielokrotność danej czynności, np: Zdarzało się, że patrzytem na ojca i dziadka i mimo woli porównywałem ich. albo mówią o osiągnięciu „skutku częściowego” tj. o sytuacji, gdy zaszły warunki konieczne, ale niewystarczające do osiągnięcia skutku (o warunkach koniecznych - Bogusławski 2003), np. Orszak podqżat wprost na nas, a my mimo woli rozstępowaliśmy się, by przepuścić idacych w uniesieniu. Podobną sytuację opisuje Duraj-Nowosielska, analizując jednostkę niechcacy (Duraj-Nowosielska 2012: 24), choć oczywiście zakres czasowników, z którymi mogą występować wyrażenia mimo woli i niechcacy nie jest taki sam - zagadnienie to jednak zasługuje na odrębną analizę. 
Kluczem do wyjaśnienia przyczyny tych ograniczeń jest przeanalizowanie przykładów (12)-(17) pod kątem perspektywy, z jakiej są one wypowiadane - o działaniu mówi się w nich z perspektywy obiektywnej ${ }^{5}$. W przykładach (12)-(14) mamy bowiem do czynienia $z$ niezamierzonym powodowaniem jakichś stanów rzeczy - np. ten, kto mimo woli wprowadził w błąd, nie wiedział, że wprowadza w błąd, po prostu (najprawdopodobniej) mówił coś, co nie było prawdą (a co uznał za prawdę) i to spowodowało, że wprowadził w błąd, a ten, kto mimo woli zademonstrował jakość mocowań, zrobił coś (tj. szarpał się), co spowodowało, że zademonstrował jakość mocowań, ale nie było tak, że miał zamiar to zrobić, itd.

Z kolei zdania (15)-(17) dotyczą czynności „,momentalnych”, związanych z ruchem (najczęściej nagłym), postrzeganiem, mimiką czy niekontrolowanymi skojarzeniami. Mowa jest w nich o tym, że (np.) ktoś zobaczył coś i się uśmiechnął, spojrzał na kogoś i pomyślał o czymś. W tych zdaniach również nie mamy do czynienia z konstrukcjami subiektywno - agentywnymi, ponieważ mowa jest w nich o tym, że coś powoduje, że $x$ robi $p$-inaczej mówiąc: robienie nie jest spowodowane wolą robiącego. Widać to dobrze, gdy porówna się przykłady (15)-(17) ze zdaniami, w których te same czasowniki wyrażają czynności zamierzone:

(22) Woskowicz ostentacyjnie spojrzat na zegarek.

(23) Skoncentrowatem się i spojrzałem na Jovankę.

(24) Dziewczynka wyglqdała na zmartwiona, więc przechodzqc uśmiechnat się do niej.

W przykładach (12)-(14) mamy do czynienia z sytuacją podobną do tej, którą można zaobserwować w zdaniach z przysłówkiem niechcacy, tj. z powodowaniem - ktoś robi coś $(p)$ robiąc coś innego $(q)$ czyli powoduje $p$, ale tylko z perspektywy obiektywnej. Jednak - w przeciwieństwie do jednostki

5 Pojęcie perspektywy obiektywnej i subiektywnej wykorzystała w swoich badaniach I. Duraj-Nowosielska, wg której perspektywa subiektywna to ,perspektywa podmiotu zdania, zakładająca odpowiednią intencję podmiotu odniesioną do danego w zdaniu obiektu. [...] Perspektywa obiektywna to podstawowa perspektywa nadawcza: nadawca wychodzi tutaj od jakiegoś „,zdarzenia skutkowego” rzeczywistego (aspekt dokonany) lub przewidywanego na podstawie obiektywnych danych" (Duraj-Nowosielska 2007: 216). 
niechcacy - wyrażeniem mimo woli można określać nie tylko zdarzenia spowodowane przez agensa ( $x$ robiąc $p$, zrobił $q$ ), ale także spowodowane czymś innym (coś powodowało, że $x$ zrobił $q$ ) - co widać chociażby w przykładzie (17). W związku z tym, formuła uwzględniająca tylko działanie agensa jako przyczynę $q$, w wypadku wyrażenia mimo woli byłaby zbyt wąska.

Jak już wspomniałam, w zdaniach (12)-(17) mamy do czynienia z konstrukcjami obiektywno-agentywnymi. Dla tego rodzaju konstrukcji, jak zauważa Duraj-Nowowsielska, ,pierwotny jest aspekt dokonany, ponieważ ich atrybucja jest ściśle związana $\mathrm{z}$ odnotowaniem przez nadawcę określonych sk u t kó w w rzeczywistości" (Duraj-Nowosielska 2012: 30).

Zupełnie inną sytuację obserwujemy w zdaniach $\mathrm{z}$ jednostką chcac nie chcac, por.:

(25) Rada miejska zażqdała od IBM oczyszczenia chodników, na co koncern, chcqc nie chcac, przystat.

(26) Coraz większa liczba dyrektorów zarzqdzajacych firmami, chcqc nie chcac, korzysta z systemu do przeszukiwania danych.

(27) Chcac nie chcac, wprowadzit Łasiczke w bład. Wiedziat, że mu ufa, więc tym bardziej nie chciat jej okłamywać, lecz nie miat wyjścia.

(28) Chcac nie chcac, sprawiła mu przykrość. Wiedziała, że jest przewrażliwiony na swoim punkcie i ta uwaga go zaboli, ale musiała to powiedzieć dla jego dobra.

W zdaniach (25)-(28) działanie ujmowane jest z perspektywy subiektywnej - agens wprowadza w błąd, sprawia przykrość (itd.) świadomie i po dokonaniu wyboru. Przykłady te pokazują również, że jednostka chcqc nie chcac może pojawić się zarówno obok czasowników wyrażających (semantyczny) aspekt dokonany, jak i tych, które wyrażają aspekt niedokonany - co widać chociażby w przykładzie (26) i w przywoływanych później zdaniach (31)-(33).

Porównanie przykładów (12)-(17) ze zdaniami (25)-(28) pokazuje ponadto, że wyrażenie chcac nie chcac implikuje robienie, natomiast jednostka mimo woli robienia nie implikuje ${ }^{6}$. Poza tym mimo woli - podobnie jak

${ }^{6}$ Co ciekawe, podobne zjawisko obserwujemy, gdy porównamy zdania z jednostkami mimo woli i mimowolnie:

(a) ?Przeciwnicy festiwalu, najpewniej mimowolnie, przypomnieli o czymś jeszcze. 
przysłówek niechcacy - nie występuje obok czasowników wyrażających czynności złożone. Duraj-Nowosielska pisze: „nie można całkiem „niechcący" zrobić czegoś, co wymaga namysłu przy poszczególnych czynnościach" (Duraj-Nowosielska 2012: 22). Wyrażenie mimo woli również nie może określać czynności złożonych, wykonywanych z namysłem i świadomie, por:

(29) *Ania mimo woli wyprasowata spodnie i marynarke.

(30) *Ania niechcacy wyprasowała spodnie i marynarkę. (oczywiście przy założeniu, że nie miała wyprasować czegoś innego)

Obok takich predykatów występuje natomiast jednostka chcqc nie chcqc - za pomocą tego wyrażenia można określać czynność, którą zawsze wykonuje się świadomie. Danielewiczowa w monografii dotyczącej pewnej klasy $^{7}$ czasowników epistemicznych, pisze o grupie predykatów - nie będących przedmiotem jej badan - „których znaczenie tworzy kombinacja niezależnych pojęć epistemicznych, przede wszystkim wiedzy, z pojęciami odpowiadającymi wykonaniu określonych czynności fizycznych. Chodzi tu o takie jednostki, jak: pilnować [czegoś], dogladać [czegoś], uważać, żeby, spieszyć się, udawać [kogoś]/ [coś], że, symulować [coś], unikać [kogoś], panować nad soba, opanować się" (Danielewiczowa 2002: 25).

Wyrażenie chcac nie chcac z większością tych czasowników tworzy konstrukcje poprawne, por.:

(b) Przeciwnicy festiwalu, najpewniej mimo woli, przypomnieli o czymś jeszcze.

(c) Uczestnik szarpnat się demonstrujqc mimo woli jakość mocowań.

(d) ?Uczestnik szarpnat się demonstrujac mimowolnie jakość mocowań.

(e) Często więc bokserem zostaje się mimo woli, by tak rzec, w samoobronie koniecznej.

(f) ?Często więc bokserem zostaje się mimowolnie, by tak rzec, w samoobronie koniecznej.

W zdaniu (a) nie może pojawić się przysłówek mimowolnie, ponieważ przeciwnicy, o których mowa, nie przypomnieli o niczym - zrobili coś, co o czymś przypomniało, natomiast mimowolnie implikuje robienie wyrażone czasownikiem - robienie z perspektywy subiektywnej. Podobnie w zdaniu (c) uczestnik nie demonstrował, tylko robił coś, co powodowało, że zademonstrował - ale tylko z perspektywy obiektywnej.

${ }^{7}$ Chodzi o klasę niefaktywnych czasowników epistemicznych (niezdarzeniowych, nieczynnościowych) $\mathrm{z}$ argumentem propozycjonalnym $\mathrm{w}$ postaci dopełnienia zdaniowego wprowadzanego przez że, np. myśleć, $\dot{z} e_{-}, u w a z \dot{a} a c ́$, że. 
(31) Michat wplatat mnie $w$ ten cyrk, więc, chcac nie chcac, udaje caty czas jego żonę.

(32) Musiat wyjść z tego z twarza, dlatego - nie znalaztszy lepszego rozwiqzania - chcac nie chcac, udawat, że jest ciężko chory.

(33) Nie znoszę tej kobiety, ale szkoda mi jej, więc, chcac nie chcac, dogladam jej dobytku, bo złodziei u nas mnóstwo.

Podobnie rzecz wygląda w wypadku czynności wykonywanych po dokonaniu wyboru odnośnie do ich rozpoczęcia. Jednostka chcqc nie chcqc pojawia się w sąsiedztwie czasowników wyrażających te czynności, nie pojawi się obok nich natomiast wyrażenie mimo woli, por.:

(34) Tego wieczoru Staś, chcqc nie chcqc, odmówit sobie wyjścia na piwo.

(35) *Tego wieczoru Staś mimo woli odmówit sobie wyjścia na piwo.

(36) Za każdym razem, chcac nie chcac, rezygnuje z tej propozycji.

(37) *Za kazdym razem mimo woli rezygnuje z tych propozycji.

(38) Chcac nie chcac, milczała - nie doniosła na niego, choć mogła.

(39) ?*Mimo woli milczała - nie doniosła na niego, choć mogła.

(40) Chłopi jednak chcac nie chcqc pozakładali spółdzielnie, a robotnicy karnie stawiali się na masówki.

(41) *Chłopi jednak mimo woli pozakładali spółdzielnie, a robotnicy karnie stawiali się na masówki.

(42) Nie byt to czas stracony, bo organizatorzy spotkania, chcqc nie chcac, wzięli na swoje barki cały ciężar dyskusji.

(43) *Nie byt to czas stracony, bo organizatorzy spotkania mimo woli wzięli na swoje barki cały ciężar dyskusji.

Można z tego wnioskować, że jeśli ktoś określa daną czynność jako wykonaną mimo woli, mówi, że nie został dokonany wybór między dwiema możliwościami - rozpoczęciem czynności i nierozpoczynaniem jej. Potwierdzać to może chociażby sprzeczność zdań zawierających jednostkę „mimo woli" i mówiących wprost o tym, że agens dokonał wyboru przed rozpoczęciem danej czynności:

(44) *Uczestnicze $w$ catym tym cyrku, ale wiem, że inni postapiliby inaczej-ja mimo woli wybratem tak. 
(45) *Wprowadziłem Łasiczkę $w$ bład mimo woli, po tym, jak dokonatem wyboru i zdecydowałem, że wprowadzę ja w bład.

(46) *Sprawitem mu przykrość mimo woli, po tym, jak dokonatem wyboru i zdecydowatem, że sprawię mu przykrość.

Kwestia wyboru i jego związku z wolą była niejednokrotnie poruszana zarówno w kontekście badań filozoficznych, jak i językoznawczych. Hannah Arendt, omawiając kwestię woli w rozważaniach Arystotelesa, pisze:

Działanie [...] wymaga rozważnego planowania, dla którego Arystoteles utworzył neologizm, proairesis. Nowy termin oznaczał wybór w sensie opowiedzenia się za jedną z możliwości. Archai tego wyboru, czyli jego zasadami lub źródłami, są pragnienie i logos: logos zaopatruje nas w cel, na którego rzecz działamy; wybór staje się punktem wyjścia samych działań. Zdolność wyboru jest pośrednią władzą umieszczoną jak gdyby w środku dawnej dychotomii pragnienia i rozumu. Jej główną funkcją jest pośredniczenie między nimi. (...) Zdolność wyboru jest konieczna wtedy, gdy człowiek działa celowo (Arendt 1996: 95$)^{8}$.

Z kolei pisząc o filozofii Augustyna, badaczka zauważa:

zdolność wyboru, tak decydująca dla liberum arbitrium, stosuje się tutaj [...] do wyboru pomiędzy velle i nolle, chceniem i niechceniem. [...] nolle jest czymś mniej aktywnym i oddziałującym niż velle - jest w takim samym stopniu władzą woli (Arendt 1996: 131).

Na związek między wolą a dokonywaniem wyboru wskazuje m. in. Grochowski: „Skoro jeżeli $x$ ma wolę, by $p$, to chce, by $p$ i $x$-owi nie jest obojętne, czy $p$ czy nie $p(. .$.$) należy przypuszczać, że osoba, która ma wolę, by p$, dokonała wyboru $p "$ (Grochowski 1980: 53).

Bogusławski pisze z kolei, że fenomen wyboru wiąże się ze „świadomością niezależności chceń i działań”, tj. ze świadomością, że „a mógł zrobić

8 Warto wspomnieć, że Arendt pisze o tym, jaki wpływ na kształtowanie się pojęcia woli miała, jej zdaniem, filozofia chrześcijańska: „Stare prawo mówiło „będziesz tak czynił”; nowe prawo mówi: „Będziesz tak chciał”. To właśnie doświadczenie imperatywu domagającego się dobrowolnego podporządkowania doprowadziło do odkrycia woli. W tym doświadczeniu uobecnił się ów zdumiewający fakt ludzkiej wolności, którego nie uświadamiał sobie żaden ze starożytnych narodów (...)” (Arendt 1996: 104). 
inaczej” (Bogusławski 1990: 206). Badacz zwraca jednak uwagę, że „wybór nie pojawia się (...) na każdym kroku" (Bogusławski 1990: 206). Wybór jest bowiem tam, gdzie - jak pisze m. in. Grochowski - ,istnieją co najmniej dwie możliwości postępowania i osoba stojąca przed wyborem jest tego świadoma" (Grochowski 1980: 54) Warto też zwrócić uwagę na to, co Arendt mówi o dyskusjach na temat woli:

W języku łacińskim Arystotelesowską władzę wybierania oddaje wyrażenie liberum arbitrium. Ilekroć natrafiamy na te słowa w średniowiecznych dyskusjach o woli, nie mamy do czynienia ani ze spontaniczną władzą rozpoczynania czegoś nowego ani z autonomiczną władzą, określoną przez swą własną naturę i słuchającą swoich własnych praw ${ }^{9}$ (Arendt 1996: 98).

Można by z tego wnioskować, że wybór wiąże się nie tylko ze świadomością, że można zrobić inaczej, ale przede ws zystkim z myśleniem ${ }^{10}$ o alternatywie, tj. o możliwości nierozpoczynania $p$ przed wykonaniem $p$ - trudno wyobrazić sobie dokonywanie wyboru co do rozpoczęcia pewnej czynności bez myślenia o niej.

Jeżeliby przyjąć słuszność zarówno twierdzenia mówiącego o związku między wyborem a wolą, jak i tezy, wg której czynność wykonana mimo woli jest czynnością wykonaną bez dokonania wyboru (odnośnie do jej rozpoczęcia), można by sądzić, iż jednostka mimo woli mówi o tym, że agens nie myślał o możliwości nierozpoczynania czynności, nie zastanawiał się nad tą alternatywą. Hipotezę tę zdaje się potwierdzać dewiacyjność zdań (47) i (48):

(47) *Tymczasem mimo woli wprowadził Łasiczke $w$ bład, a zanim ja wprowadził w bład myślat o tym, że może tego nie robić.

(48) *Czerwony Kapturek mimo woli oddalit się od ścieżki, a zanim oddalit się od ścieżki myślał o tym, że może się nie oddalać.

9 Dalej Arendt przytacza następujący przykład: „(...) osioł Buridana: biedne zwierzę zagłodziłoby się na śmierć stojąc pomiędzy dwiema równo oddalonymi i równie wonnymi kupkami siana, ponieważ żadne rozważanie nie dostarczyło mu powodu do wybrania którejś z nich. Uratowało się tylko dlatego, że było wystarczająco mądre, aby zrezygnować z wolnego wyboru, zaufać swoim pragnieniom i pochwycić pierwszą lepszą" (Arendt 1996: 98).

10 Warto uściślić pewną kwestię: jeśli myślimy o czymś, to również wiemy o tym, ale jeśli nie myślimy o czymś, to nie znaczy, że o tym nie wiemy. 
$\mathrm{Z}$ nieco podobną sytuacją mamy do czynienia w wypadku jednostki odruchowo - agens (który zrobił $p$ odruchowo) mógł wiedzieć (mógł też nie wiedzieć), że robił $p$, ale ani przed zrobieniem $p$, ani w trakcie robienia $p$ nie myślał o $p$ (pisałam o tym w innym miejscu - (Żochowska 2013)). Należy jednak zwrócić uwagę na to, że przysłówek odruchowo dotyczy niemyślenia o czynności (o $p$ ), natomiast wyrażenie mimo woli - niemyślenia o wspomnianej alternatywie nierozpoczynania $p$.

Słuszność przywoływanych wcześniej hipotez (dotyczących pojęcia wyboru) musiałaby się wiązać również z obecnością w strukturze badanej jednostki informacji o braku „chcenia” i „niechcenia” agensa. O obecności tej informacji świadczyć może niesprzeczność następujących zdań, por.:

(49) Nieprawda, że Janek chciat Cię zranić - zranit Cię mimo woli.

(50) Ania zaczęła stuchać opowiadania po prostu mimo woli, ale nieprawda, że nie chciała go stuchać.

Można z tego wnioskować również, że badane wyrażenie - wbrew temu, co sugerują definicje słownikowe - nie znaczy 'wbrew woli'. Potwierdza to chociażby poprawność takich zdań, jak:

(51) Czerwony Kapturek oddalat się od ścieżki mimo woli, ale nie wbrew woli. Po prostu zbierat poziomki i nie wiedziat, że jest coraz dalej od obranej drogi.

(52) Wróciłam ze spotkania i jestem chora od papierosów wypalonych mimo woli, ale nie wbrew woli.

(53) Wtedy też mimo woli wszedtem na droge prowadzaca do dziennikarstwa, ale nieprawda, że wszedtem na tę drogę wbrew własnej woli.

Zdania (34), (36), (38), (40) i (42) pokazują, że wyrażenie chcac nie chcac - w przeciwieństwie do jednostki mimo woli - może występować obok czasowników wyrażających czynności wykonywane po dokonaniu wyboru (odnośnie do ich rozpoczęcia). Co ciekawe, jednostki chcqu nie chcąc można użyć również w odniesieniu do sytuacji, gdy osoba robi coś, choć nie dokonała wyboru, por..:

(54) Chcac nie chcqc, stucham ich wywodów. 
(55) Chcac nie chcac, jesteś od niej uzależniony.

(56) Jako dziecko, chcac nie chcqc, brałem udział w życiu finansowym rodziny.

Oznacza to, że wyrażenie chcqc nie chcqc nie zawiera w swojej strukturze informacji mówiącej o dokonywaniu wyboru odnośnie do rozpoczęcia czynności, jest pod tym względem neutralne. Z kolei zdania (27) i (28) moga sugerować, że jednostka chcac nie chcqc odnosi się do czynności w ściśle określonej sytuacji. Wg definicji słownikowych, jeśli robimy coś chcąc nie chcąc, to robimy to „z konieczności” (SJPDor, SJPSz, SWJP) lub jesteśmy „zmuszeni przez jakąś osobę lub sytuację” (ISJP) i robimy to „nie z własnej woli” (ISJP) lub nawet „wbrew własnej woli” (SJPDor, SJPSz, SWJP, USJP). Część cytowanych słowników definiuje znaczenie tego wyrażenia również za pomocą badanej w tym artykule jednostki mimo woli (SJPDor, USJP), co - jak można się domyślać na podstawie wskazanych już różnic między analizowanymi wyrażeniami - nie jest słuszne ${ }^{11}$.

W cytowanych definicjach mowa jest również o tym, że jednostka chcac nie chcac wyraża konieczność, nie sprecyzowano jednak, czy pojęcie to należy rozumieć w kategoriach modalności deontycznej czy aletycznej. Modalność zdań stanowiących ilustrację materiałową do tych definicji wynika często ze znaczenia występujących tam czasowników, a nie ze znaczenia jednostki chcac nie chcac.

W korpusach języka polskiego (PWN i IPI PAN) jest wiele zdań, w których wyrażenie chcac nie chcac stoi w sąsiedztwie predykatu wyrażającego modalność deontyczną ${ }^{12}$ musieć, np.:

11 Na marginesie warto wspomnieć, że Samuel Bogumił Linde w swoim słowniku odnotowuje jednostki uznane przez siebie za odpowiedniki polskiego chcac nie chcac w innych językach, m.in.: Slovac.: chtj nechtj, Boh.: wol neb newol, wolky newolky (SJPL).

12 Za predykaty wyrażające modalność deontyczną uważam - za Holvoetem - te wyrażenia, które oznaczają ,postępowanie wskazane w określonych warunkach” lub „obowiązek" (Holvoet 1989: 131). W zdaniach (57)-(60) wyrażenie musi dotyczy postępowania wskazanego w określonych warunkach.

Czasowniki występujące w powyższych przykładach zaliczyłam do deontycznych predykatów modalnych ze względu na podobieństwo tych zdań do analizowanych przez Holvoeta przykładów:

(A) W tej sytuacji musiatem wyjechać, nie miatem wyboru.

(B) Choć mi się nie chce, muszę wyjechać., 
(57) Chcqc nie chcac, oboje musieli przejść przyspieszony kurs obracania się $w$ polskiej rzeczywistości.

(58) Sobotni finat byt rozproszony jak fajerwerk. Chcac nie chcac, musieliśmy więc wybierać.

(59) Przy tym dramatycznym ruchu stracił równowagę i chcac nie chcac, musiat zeskoczyć w sam środek kałuży.

(60) Wyczerpani, chcqu nie chcqu, musieliśmy udać się na spoczynek.

Obecność w znaczeniu jednostki chcac nie chcac komponentu 'musi' rozumianego w kategoriach modalności deontycznej wydaje się zatem wątpliwa, ponieważ, jak pisze Danuta Rytel „w ramach poszczególnych typów modalności ich przeciwstawne znaczenia wzajemnie się wykluczają, tak więc, np. dane wypowiedzenie nie może być równocześnie oznajmieniem i rozkazem czy dany sąd nie może być jednocześnie realny i nierealny, pewny i niepewny. Podobnie w jednym wypowiedzeniu nie występują z reguły dwa środki służące tej samej modalności" (Rytel 1982: 156-157). Gdyby badana jednostka wyrażała modalność deontyczną, zdania (57)-(60) byłyby pleonastyczne, a nie sa.

Argumentem podważającym słuszność hipotezy mówiącej o obecności w znaczeniu badanej jednostki wspomnianego składnika 'musi' jest również niesprzeczność następujących zdań, por.:

(61) Wszyscy się gdzieś rozpierzchli i teraz, chcac nie chcqc, sama pilnuje catego gospodarstwa, chociaż nie muszę.

(62) Michat wplatał mnie $w$ ten cyrk, więc, chcac nie chcac, udaje caty czas jego żone, chociaż nie muszę tego robić.

(63) Nie znoszę tej kobiety, ale szkoda mi jej, więc, chcą nie chcac, dogladam jej dobytku, chociaż nie muszę tego robić.

reprezentujących, jego zdaniem, właśnie modalność deontyczną. Holvoet pisze: „Na pierwszy rzut oka mogłoby się wydawać, że w tych zdaniach brak elementu wolitywnego i że czasownik musieć wyraża konieczność aletyczną. Każde świadome postępowanie człowieka zakłada akt woli. Zakłada go również użycie wyrażenia muszę w zdaniach (A), (B). Wypowiadający zdanie (B) ma w rzeczywistości możliwość wyboru, choć jedno z możliwych postępowań może mieć nieprzyjemne dla niego skutki” (Holvoet 1989: 130). 
Do predykatów wyrażających konieczność deontyczną Holvoet zalicza również czasownik powinien. Zaznacza jednak, że „oba czasowniki moga wskazywać zarówno na obowiązek, jak i na to, że określone postępowanie jest wskazane w danych warunkach" (Holvoet 1989: 129). Należy zatem zadać pytanie, czy wyrażenie chcac nie chcqc nie wyraża powinności. Odpowiedzi nie trzeba daleko szukać - gdyby w znaczeniu badanej jednostki zawarty był komponent mówiący o powinności, nie mogłaby ona tworzyć poprawnych konstrukcji z czasownikami, które wyrażają czynności, zachowania czy stany niezwiązane z wypełnianiem obowiązków czy spełnianiem powinności, a także z tymi, które mówią o działaniach ocenianych jako złe ${ }^{13}$. Konstrukcje takie natomiast są możliwe - widać to w takich zdaniach, jak:

(64) Chcac nie chcac, zaczynasz zachowywać sie jak pies ogrodnika.

(65) Do tej zażyłości nie była może usposobiona, ale, chcac nie chcqc, zaznała stąd radości tęgiej jak kielich miodu.

Gdyby natomiast badane wyrażenie było predykatem modalności aletycznej ${ }^{14}$, należałoby sądzić, że wyrażenie to implikuje dwa sądy o świecie i mówi o relacji między nimi. Według Holvoeta ,zdania wyrażające konieczność aletyczną mają postać 'D tylko, jeśli N' "'

(66) Żeby zdażyć na pociag (D), musiała już wyjść (tylko jeśli N).

(66a) Tylko jeśli już wyjdziesz, zdażysz na pociag.

(67) Żeby usunqć mnie z mieszkania (D), komornik musiat mnie z niego wynieść $(N)^{15}$.

(67a) Usunie mnie z mieszkania, tylko jeśli wyniesie mnie z niego.

13 O różnych interpretacjach powinności pisze Elzenberg, omawiając relacje między tym pojęciem a m. in. pojęciem wartości czy woli (Elzenberg 1990).

14 Wg Holvoeta, modalność aletyczna dotyczy „relacji między dwoma sądami w odniesieniu do pewnego możliwego świata, czasowo ograniczonego" (Holvoet 1989: 21),

15 Holvoet (w związku z tym, że jego praca dotyczy modalności i aspektu) ilustruje modalność aletyczną następującym przykładem:

A niechaj komornik przyprowadzi ze sobq dwu stójkowych, bo mnie będq musieli wynosić z mieszkania.

Wg badacza, zdanie to wyraża relację między dwoma predykatami: usunięcie lokatora z mieszkania jest możliwe tylko jako wynik pewnego działania - niesienia. Znaczenie „usunięcia zawarte jest w semantyce czasownika dokonanego wynieść, natomiast działanie w znaczeniu odpowiednika niedokonanego" (Holvoet 1989: 139). 
Co ciekawe, jednostka chcą nie chcac pojawiając się w sąsiedztwie predykatu musieć w kontekstach, takich jak (66) i (67) nie wpływa na poprawność zdania, por.:

(68) Żeby zdażyć na pociag, chcqc nie chcac, musiała już wyjść.

(69) Żeby usunqć Wanię z mieszkania, komornik, chcac nie chcac, musiat go stamtad wynieść.

(70) Żeby dostać się na studia, chcqc nie chcac, musiała ślęczeć nad ksiażkami.

(71) Żeby nie zmarnować sobie reszty życia, chcac nie chcac, musiała podjać leczenie.

Świadczyć to może o braku w strukturze semantycznej badanego wyrażenia komponentu, który wyrażałby modalność aletyczną - w przeciwnym wypadku zdania (68)-(71) byłyby pleonastyczne.

Warto też przywołać takie zdania z jednostką chcac nie chcac, w wypadku których mowa jest o tym, że dzieje się z nami coś, dlatego że coś dany stan spowodowało, ale nie można tej relacji nazwać koniecznością. Chodzi o zdania takie jak:

(72) Z czasem człowiek tęskni coraz mniej, ale zaraz po powrocie, chcac nie chcac, wszystko porównuje.

(73) Kiedy byłaś małym dzieckiem, chcac nie chcac, uczestniczyłaś w życiu finansowym swojej rodziny.

(74) Ten, kto czyta sutry, chcac nie chcac, caty czas ustanawia odrębność swojego ,ja".

(75) Czekając na zamówiony panel, postanowitem dowiedzieć się co nieco o technologii i chcac nie chcac, trafitem na strony Microsoftu.

We wszystkich zdaniach z jednostką chcac nie chcac mowa jest o tym, że działanie agensa jest czymś spowodowane ${ }^{16}$, co widać chociażby w przykła-

16 W zdaniu (68) q - chce zdążyć na pociąg, w zdaniu (69) q - (komornik) chce usunąć mnie z mieszkania, w zdaniu (70) q - chce dostać się na studia, w zdaniu (71) - nie chce zmarnować sobie reszty życia, w zdaniu (72) q - tęskni, w zdaniu (73) q - byłam małym dzieckiem, w zdaniu (74) q - czyta sutry, w zdaniu (75) q - postanowiłem zapoznać się z technologią. 
dach (27) i (28), (31)-(33) czy (68)-(75). Mówi ona zatem, że jest coś (q), co powoduje, że $x$ robi $p$. $Q$ może oznaczać jakąś relację, związek między dwoma stanami rzeczy, np. konieczność - wtedy, $x$ robi $p$, dlatego że jest to konieczne. Może też oznaczać jakiś stan rzeczy. Istotne jest, żeby zdać sprawę $z$ tego, że informacja o tym, ze względu na jaką relację czy stan rzeczy $x$ robi $p$ zawarta jest $\mathrm{w}$ kontekście, a nie $\mathrm{w}$ znaczeniu jednostki chcac nie chcqc. W strukturze semantycznej tego wyrażenia zawarta jest informacja o tym, że $x$ robi $p$, dlatego, że $q$.

W literaturze filozoficznej i językoznawczej niejednokrotnie mówi się o tym, że działanie nie ma przyczyn - pisze o tym chociażby Łukasiewicz (1961), Ryle (1970), czy Duraj-Nowosielska (2007). Mówi się za to o motywach działania, o skłonnościach lub o tym, że ktoś ma predyspozycje do tego, by działać w określony sposób (Ryle 1970). Natomiast jednostka chcqc nie chcac dotyczy właśnie tego działania, o którym powiedzielibyśmy, że ma przyczynę, czyli nie jest podejmowane dlatego, że ktoś chciał robić $p$, lecz dlatego, że coś spowodowało, że robił $p$. Nie było natomiast tak, że $x$ chciał robić $p$, o czym świadczy sprzeczność następujących zdań:

(76) *Chcac nie chcac, uczestniczyłam $w$ życiu finansowym rodziny $i$ chciałam $w$ tym uczestniczyć.

(77) *Chcac nie chcac, pilnuję catego gospodarstwa i chcę pilnować catego gospodarstwa.

(78) *Czekajac na swoja kolej, chcqc nie chcac, stucham ich wywodów i chcę stuchać ich wywodów.

Komponent 'nie było tak, że chciał' nie wyklucza możliwości 'nie chciał', ponieważ brak chcenia $p$ jest sprzeczny tylko z chceniem $p$ - Bogusławski pisze o tym w sposób następujący: „W danym momencie podmiot po prostu bądź chce, by p bądź jest takiego chcenia pozbawiony" (Bogusławski 1990: 209). Niesprzeczność poniższych przykładów potwierdza słuszność hipotezy mówiącej, że wyrażeniem chcqc nie chcqc można określić czynność, której osoba wykonująca nie chce robić, por.:

(79) Chcac nie chcac, udaję żonę Michała, chociaż wcale nie chcę tego robić.

(80) Chcac nie chcac, uczestniczyłam w życiu finansowym rodziny, chociaż nie chciałam w nim uczestniczyć. 
(81) Wszyscy się gdzieś rozpierzchli i teraz, chcac nie chcac, pilnuje gospodarstwa, chociaż wcale nie chcę tego robić.

Jak już wspomniałam, jednostka ta - w przeciwieństwie do wyrażenia mimo woli - nie mówi nic o tym, czy agens dokonał wyboru odnośnie do rozpoczęcia czynności. Jeżeli mówimy, że ktoś zrobił coś mimo woli, to mówimy, że nie było tak, że chciał, bo nie dokonał wyboru, tj. nie myślał o alternatywie - o tym, że może nie zrobić $p$. Natomiast, jeśli mówimy, że ktoś robi coś chcąc nie chcąc, mówimy, że robi to nie dlatego, że chce, ale dlatego, że $q$. Nie mówimy natomiast nic o dokonywaniu wyboru - w każdym razie informacji o tym nie ma w znaczeniu jednostki chcac nie chcqc, choć może być w kontekście.

O tym, że gdy robimy coś ( $p$ ) chcąc nie chcąc, możemy widzieć alternatywę (i robić $p$ po dokonaniu wyboru), świadczyć może zarówno poprawność zdań (34), (36), (38), (40) i (42), jak i brak sprzeczności w następujących przykładach, por.:

(82) Chcac nie chcac, uczestniczę w tym całym cyrku, ale wiem, że inni postapiliby inaczej-ja wybratem tak.

(83) Chcac nie chcac, wybratem tę drogę.

Z kolei analizowane wcześniej przykłady (54)-(56) pokazują, że można robić coś chcąc nie chcąc nie dokonawszy wyboru - w zdaniach tych mowa jest o czynnościach wykonywanych zupełnie niezamierzenie.

Powiedziałam wcześniej, że jeżeli określamy jakąś czynność jednostką mimo woli, to mówimy, że czynność ta została wykonana bez wcześniejszego dokonania wyboru. Wybór ten (gdyby go dokonywano) byłby wyborem między rozpoczęciem czynności $p$ a nierozpoczęciem. W związku z powyższymi ustaleniami, należałoby rozumieć, że jeżeli $x$ mimo woli zrobił $p$ znaczy, że $x$ nie dokonał wyboru, że zrobi $p$ (zamiast nie zrobić $p$ ) i nie było ani tak, że chciał zrobić $p$, ani tak, że nie chciał zrobić $p$. Natomiast, jeśli ktoś robi coś $(p)$ chcąc nie chcąc, robi to, dlatego że $q$ i nie jest tak, że chce robić $p$.

Przedstawiona analiza mająca na celu ustalenie komponentów semantycznych jednostek mimo woli i chcqc nie chcqc skłania mnie do zaproponowania następujących eksplikacji: 
x mimo woli zrobił $\mathrm{p}$ :

'x nie był gotów powiedzieć17, że może nie zrobić $\mathrm{p}$

i nie było tak, że chciał zrobić p'

$\mathrm{x}$, chcąc nie chcąc, robi p:

'x robi $\mathrm{p}$ dlatego, że $\mathrm{q}$

i nie jest tak, że chce robić p'

\section{Bibliografia}

Arendt H., 1996, Wola, przeł. R. Piłat, Warszawa: Spółka Wydawnicza „Czytelnik”. Arystoteles, 1956, Etyka Nikomachejska, przeł. i oprac. D. Gromska, Warszawa: Państwowe Wydawnictwo Naukowe.

Bá́ko M. (red.), 2000, Inny stownik języka polskiego, Warszawa: Wydawnictwo Naukowe PWN.

BogusŁawski A., 1990, O „wolności woli”, Etyka 25, s. 191-227.

BogusŁawski A., 1993, O proporcjonalności w języku i jej warunkach, w: J. Sambor, J. Linde-Usiekniewicz, R. Huszcza (red.), Językoznawstwo synchroniczne i diachroniczne. Tom poświęcony pamięci A. Weinsberga, Warszawa: Wydawnictwa Uniwersytetu Warszawskiego.

${ }^{17}$ Formułę ‘jest gotów powiedzieć'(zamiast 'myśli o') stosuje m. in. Danielewiczowa, opisując znaczenie czasowników epistemicznych. Wg badaczki, argumentami przemawiającymi za istnieniem ścisłego związku między stanami epistemicznymi a mówieniem jest:

- fakt, że „ogromna większość predykatów propozycjonalnych [...] może być poprawnie odniesiona tylko do istot mówiących" (Danielewiczowa 2002: 98);

- to, że ,pewne czasowniki stricte mentalne już swoją formą odsyłają wprost do działań językowych, [...] np. być zdania, że_czy powiedziatbym, że_" (Danielewiczowa 2002: 99);

- ,strukturalne podobieństwo verbów sentendi do verbów dicendi [...] tylko te dwie klasy wyrażeń mają w języku naturalnym charakter propozycjonalny" (Danielewiczowa 2002; 101).

Danielewiczowa zaznacza jednak, że w wypadku stosowanego przez nią wyrażenia a jest gotów powiedzieć, że p, ,,akcent zdaniowy może spoczywać wyłącznie na propozycjonalnym dopełnieniu p" (Danielewiczowa 2002: 104), pokazując tym samym, że różni się ono od funkcjonującej też w języku polskim konstrukcji ktoś jest gotów (do tego), żeby. . 
BogusŁawski A., 2003, Aspekt i negacja, Warszawa: Instytut Lingwistyki Stosowanej i Katedra Lingwistyki Formalnej UW.

Danielewiczowa M., 2002, Wiedza i niewiedza. Studium polskich czasowników epistemicznych, Warszawa: Katedra Lingwistyki Formalnej UW.

Doroszewski W. (red.), 1996, Słownik języka polskiego, Warszawa: Państwowe Wydawnictwo Naukowe.

Dubisz S. (red.), 2003, Uniwersalny słownik języka polskiego, Warszawa: Państwowe Wydawnictwo Naukowe.

Dunau B. (red.), 1996, Słownik współczesnego języka polskiego, Warszawa: Wilga.

Duraj-Nowosielska I., 2007, Robić coś i coś powodować, Warszawa: Wydział Polonistyki Uniwersytetu Warszawskiego.

Duraj-Nowosielska I., 2012, Nie przypadkiem o niechcacy, Warszawa: Wydawnictwo Uniwersytetu Kardynała Stefana Wyszyńskiego.

Elzenberg H., 1990, Wartość a powinność (Tekst żemłosławski), Etyka 25, s. 17- 45.

Grochowski M., 1980, Pojęcie celu: studia semantyczne, Wrocław: Zakład Narodowy im. Ossolińskich.

Holvoet A., 1989, Aspekt a modalność w języku polskim na tle ogólnosłowiańskim, Wrocław: Zakład Narodowy im. Ossolińskich.

Linde S. B., 1807-1814, Słownik języka polskiego, Warszawa: Drukarnia XX. Piiarów.

ŁukASIEwICz J., 1961, Analiza i konstrukcja pojęcia przyczyny, w: idem, Z zagadnień logiki i filozofii, Warszawa: Państwowe Wydawnictwo Naukowe, s. 114-128.

Ryle G., 1970, Czym jest umyst?, przeł. W. Marciszewski, Warszawa: Państwowe Wydawnictwo Naukowe.

Rytel D., 1982, Leksykalne środki wyrażania modalności w języku czeskim i polskim, Wrocław: Zakład Narodowy im. Osolińskich, Wydawnictwo PAN.

Szymczak M. (red.), 1995, Słownikjęzyka polskiego, Warszawa: Państwowe Wydawnictwo Naukowe.

WróBel H., 1975, Składnia imiesłowów czynnych we współczesnej polszczyźnie, Katowice: Uniwersytet Śląski.

Żochowska N., 2012, Czy „mimo woli” jest jednostką języka?, Tekstura 1(3), s. 171-183.

Żochowska N., 2013, Charakterystyka semantyczna jednostki odruchowo na tle innych przysłówków dotyczących myślenia, woli i świadomości, Poradnik Językowy 9, s. 57-66. 


\section{Semantic characterisation of expressions chcac nie chcqu and mimo woli ( s u m mary)}

The article discusses lexical units chcac nie chcac and mimo woli, which are used in contemporary Polish. Firstly, the author justifies why she considered chcac nie chcac and mimo woli as lexical units. Later, she describes features of the expressions under discussion by showing restrictions in their lexical collocations. Among other things, the author investigates whether there is a component communicating necessity in the expression chcac nie chcac and whether the unit mimo woli refers to a moment preceding the initiation of an action. The analysis conducted in the article shows that when we describe an activity with the expression mimo woli, we declare that somebody did not decide on initiating it. Whereas the expression chcac nie chcac, states that something caused a given action and that it was not the will of the person who initiated it to do so. At the end of the article, the author presents the semantic explications of the expressions studied. 
